\title{
Oil Import Diversification in Northeast Asia: A Comparison Between China and Japan
}

\author{
Vlado Vivoda and James Manicom
}

\begin{abstract}
In this article, we explore why oil import patterns differ between states with a view to understanding the relationship between agent-based explanations such as strategy and structural explanations-for example, geography. We compare degree of diversification between China and Japan in an effort to explore the relationship between agency and structure in the formation of energy security policy. The China-Japan comparison is contextualized with reference to the baseline case of the United States, a well-diversified importer. We employ the ShannonWiener index of diversity to assess the extent of oil import diversification, and temporal changes in diversification for China, Japan, and the United States. A key finding is that China's statist approach has allowed it to diversify its sources of imported oil more quickly than Japan's hybrid approach. In fact, since becoming a net oil importer in 1993, China's sources of imported oil have diversified quite rapidly. Japan's overreliance on the Middle East for much of its imported oil has been endemic since 1973. KEYworDs: China, Japan, oil imports, diversification, energy security, geography, strategy
\end{abstract}

Safety and security in oil lie in variety and variety alone.

—Winston Churchill

OIL IS THE KEY TO THE ENERGY SECURITY OF ENERGY-IMPORTING COUNTRIES, and concerns about the security of oil imports dominate energy policy thinking and making. Indeed, for many policymakers, energy security equates to oil security (Alhajji 2007). Moreover, the vast majority of the literature on energy security focuses on oil (Fried and Trezise 1993; Stringer 2008), and oil is viewed as the most important traded commodity in the world economy (Noreng 2002). With a 35 percent share in 2009, oil is the world's most widely used source of energy, and with 2,600 million tons of crude oil and petroleum products traded in 2009- three times more 
than natural gas and liquefied natural gas (LNG) trade combined-it is the most traded energy resource (BP 2010). Importantly, the oil market is the benchmark for other energy and commodity markets and is the most imbalanced of all energy markets. The Asia-Pacific region, Europe, and North America consume approximately 80 percent but control only 10 percent of the world's oil reserves. At the same time, Africa, the former Soviet Union, the Middle East, and South America consume 20 percent, while controlling 90 percent of the world's remaining oil reserves (BP 2010). This geographic imbalance presents a significant challenge to insecure energy-consuming states.

Energy-importing states adopt a variety of strategies to provide for energy security, which are almost exclusively designed to mitigate the risks associated with supply disruption. These include diversification of types of fuels used, diversification of transport routes, measures to secure access to energy at the source (i.e., through equity oil), energy conservation, energy efficiency, technological innovation, stockpiling, increased domestic production, improvements in energy infrastructure, increased international cooperation among the importers, and improved political relations with the exporters.

A final method, arguably the most important if Churchill is to be believed, is the diversification of import sources: trying to import energy supplies from as many different regions and countries as possible. Diversification militates against supply disruptions due to political or environmental crises in one area of the world. While there are many components to a diversified oil import portfolio, two government strategies have attracted much attention in recent years: resource diplomacy and equity stakes. The former is a process by which an importing state uses the edifice of foreign policy tools to gain preferential access to an exporting state's upstream and downstream energy sectors. The latter aims to ensure a degree of supply security by allowing the importing state to buy resources directly from producer countries rather than from the spot market. Governments work with a variety of actors to pursue this policy aim, including national oil companies, independent oil companies, and foreign affairs specialists. Many scholars and policymakers view them to be inherently antimarket strategies and thus, for example, inimical to US interests (Friedberg 2006). Indeed, the bulk of the literature on energy security has assessed the implications of these strategies for bilateral, regional, and international relationships (Herberg 2004; Kreft 2006; Lai 2007; Mitchell and Lahn 2007; Tow 2007).

The logic for diversifying the source of oil imports is simple. A majority of key oil exporters, particularly those located in the Middle East, 
Africa, and Latin America, suffer political instability or have a high risk potential for it, and this places importers at risk. A nation that relies heavily on international markets for oil imports faces a multitude of potential disruptions to the availability of oil. Disruptions are any events that lead to imbalances between supply and demand in the international oil market, and they can occur as a result of political, market, and accidental and natural events, or a combination thereof (Lesbirel 2004). Over the past decades, there have been numerous oil supply disruptions, and these have increased the price of oil and negatively affected the global economy, particularly oil importers. A wise oil-importing government will seek to diversify its supplier mix either directly through state strategies or indirectly through private actors to reduce economic vulnerability to future disruptions or the failure of any one producer to provide adequate supplies. This portfolio approach mitigates the risks of the international oil market provided it is accomplished with acceptable economic and political costs (Lesbirel 2004; Neff 1997; Wu et al. 2007).

We assess in this article the relationship between different oil security strategies and the extent of diversification of sources of imported oil. Despite similarities in the objective of diversifying imports, patterns of import diversification vary cross-nationally, with concomitant effects on energy security. We explore here Chinese and Japanese approaches to oil import diversification and attempt to explain why their patterns of oil imports differ, despite having a common objective of achieving greater diversification as well as being located in the same geographic region for the purposes of seaborne transportation. There is little consensus in the literature as to what ingredients account for differences in patterns of oil import diversification (Vivoda 2009). For example, there is an argument that a willingness to befriend rogue regimes allows an importer to maximize import sources (Lee 2005). Some argue that state-centric factors, such as the relationship between government and the oil industry, account for the rate of diversification (Koike, Moji, and Albedaiwi 2008). By contrast, we argue that strategies are only part of the explanation. Geographic factors such as a state's location relative to the global distribution of oil are part of the explanation.

With a view to understanding the relationship between agent-based explanations such as strategies, and structural explanations such as geography, we explore why oil import patterns differ between states. We compare degree of diversification between China and Japan in an effort to explore the relationship between agency and structure in the formation of energy security policy. The China-Japan comparison is contextualized with reference to the case of the United States, which is the world's largest 
oil importer and, as will be illustrated in a subsequent section, a well diversified importer.

We begin our discussion by developing a three-fold typology of energy security strategy: market based, state based, and hybrid . Next, we employ the Shannon-Wiener index of diversity to assess the extent of oil import diversification and temporal changes in diversification for China, Japan, and the United States. The findings indicate that China's oil imports are more diversified than Japan's because its statist approach has allowed it to change the sources of its imported oil more quickly than Japan's hybrid approach. Japan's sources of imported oil remain undiversified, characterized by the country's overreliance on the Middle East, something that China has avoided. We then explain the differences in degrees of diversification between China and Japan in the context of the relationship between oil security strategies and geographic constraints. While China and Japan are located in the same region, geographic differences have affected their choices of preferred energy security policy. Inasmuch as Chinese and Japanese energy policies are often considered in tandem, not least because of their apparently competitive nature (Calder 1996; Herberg 2004; Liao 2007), we conclude by assessing the implications for studies on energy security policy and for the China-Japan relationship.

\section{Oil Security Strategies}

Energy security means the same thing to all importing states: ensuring the availability of sufficient energy supplies at affordable prices (Yergin 1988, 111). The same may be said for oil security. A further point of consensus between states is that diversification of oil import sources can provide a degree of insurance against the risk of supply disruption from a particular geographic area. Despite this consensus on the appeal of some form of diversification strategy, not all states pursue oil import diversification, or indeed oil security, in an identical fashion. In this section, we outline three types of oil security strategies pursued by three major importers: the United States, China, and Japan. We argue that these states have in fact pursued three distinct types of oil security strategy that reflect key differences in their political economies.

The United States has adopted a market approach that seeks to mitigate the risk of supply disruption by enhancing the efficiency of domestic and international markets. With the regular discovery of new oil deposits and the development of international energy markets, oil has become less strategic and thus should be dealt with via market mechanisms. 
Government intervention is only needed in times of a market failure (Constantin 2005; Liao 2009). China, by contrast, has adopted a statist approach that emphasizes state control of resources and favors a major role by the government in sponsoring energy-related activities, such as direct government participation in both enhancing domestic energy production and in investing in the upstream sectors of producer states. Other components of the state approach include the pursuit of energy diplomacy and provision of foreign assistance (Andrews-Speed, Liao, and Dannreuther 2002; Liao 2009). It could be argued that there is nothing unique about this approach, as it has been reflected to varying degrees by other importer states such as South Korea, India, and Japan (Xu 2006). Japan has adopted a hybrid approach that combines market and nonmarket strategies.

\section{US Market Approach}

Since the first oil crisis, in 1973, diversifying and guaranteeing its energy supply has been a priority for the United States. Despite efforts to increase energy efficiency and develop alternative energy sources, energy security has continued to be equated with uninterrupted oil supply at reasonable price levels. Although the US government considers energy security, and particularly the security of oil supplies, an important security issue, the government plays no direct role in the procurement of oil supplies. For the past three decades US policy has, in large measure, stressed the importance of markets. For instance, while the 2001 National Energy Policy stressed the importance of oil import diversification as a goal, greater diversification was to be achieved by advancing technology, improving the investment climate in new sources of oil, and facilitating the flow of investment and technology (NEPDG 2001, 133-135). US policy encourages the move to more efficient markets by, for example, encouraging countries to remove subsidies for energy and by maintaining the open oil market trading rules. The belief is that if markets are open, economic forces will naturally encourage greater efficiency (Deutch, Schlesinger, and Victor 2006).

This policy is underwritten by the belief that oil production and security can best be achieved by private companies, which are the most efficient. For decades, the United States has actively encouraged private sector oil production that supports effective functioning of the markets. In many ways, US government strategy offloads the diversification risk on to private entities. ${ }^{1}$ This includes discouraging government involvement in the functioning of all segments of the oil and gas industry. One 
of the main aims of this policy has been to reduce the usage of oil as leverage for non-oil political purposes, exemplified by actions taken by the governments of Russia, Iran, Sudan, and Venezuela in recent years.

Consequently, the United States has relied on private companies to supply the country with imported oil. The international oil companies (IOCs) in particular have historically played an important energy security role (Vivoda 2010b). After World War II, IOCs assured the United States and the rest of the non-Communist world a secure supply of relatively cheap oil through their extensive development of Middle Eastern and other non-Western sources of oil (Gilpin 1975). Amy Myers Jaffe and Ronald Soligo (2007) argue that in the 1980s, following the oil crises, exploration spending by IOCs spurred a large increase in non-OPEC oil production, promoting diversity of supply and enhancing US energy security in the 1980s and 1990s. By encouraging private entrepreneurship and developing efficient markets and domestic distribution systems, the United States facilitates oil imports from multiple regions. Since the 1973 oil crisis, imports from regions such as South America, Africa, Europe, and Central Asia have increased. The pursuit of a hemispheric energy policy has been considered a cornerstone in ensuring US energy security and reducing dependence on oil imports from the Middle East (Salameh 2003). Importing oil from producers in geographic proximity reduces transportation cost and thus the oil price. In particular, the creation of the North American Free Trade Area (NAFTA) in 1993, which eliminated tariffs on oil imports from Mexico and Canada, has made the oil prices lower and has thus provided incentives for US and other oil companies to increase production in these two contiguous states. Overall, increased IOC exploration and production in non-OPEC regions promotes US diversity of supply and enhances US energy security.

\section{China's Statist Approach}

Beijing's motivation to ensure energy security is driven by the scale of its projected consumption growth. Despite its significant, albeit peaking, onshore production, China's demand for oil imports is forecast to more than double by 2020 (Shealy and Dorian 2007); thus diversification is in part driven by the necessity to acquire as much oil as possible. The political legitimacy of the Chinese Communist Party (CCP) is tied to its ability to provide for the economic welfare of China's citizens, which cannot be accomplished if domestic oil prices skyrocket or if there is a supply shortage. China's statist oil security policy is composed of three factors: state direction over the activities of state-owned oil companies, the pursuit of global equity stakes, and energy diplomacy. 
The Chinese state takes a direct interest in ensuring the domestic supply of oil by directing the activities of its national oil companies (NOCs). China's NOCs have historically had defined roles: the China National Offshore Oil Corporation (CNOOC) was responsible for offshore operations while the China National Petroleum Corporation (CNPC) was responsible for onshore oil production. Reforms instituted in 2001 were designed to increase competitiveness of these entities, both domestically and internationally, and included the creation of Sinopec. As these corporations have become more profit-oriented, they have at times drifted from central control. This has exacerbated the lack of central oversight over China's energy policy, which has been characterized by bureaucratic incoherence (Kong 2009; Zha 2006). There is evidence that the policy formulation process is becoming more coherent and streamlined, but Beijing still does not have an overarching coordinating body on energy policy (Lester and Steinfeld 2006). Despite the creation of the National Energy Administration in 2008 and a higher-ranking coordinating body in January 2010, Chinese energy policy remains hostage to a number of competing actors and interests (Downs 2008; Wan 2010). China's NOCs, however, are among the most coherent and influential policy actors, at least when it comes to China's "going out" strategy (Meiden, Andrews-Speed, and Ma 2009). While some argue that CNOOC, CNPC, and Sinopec are still relatively backwards by global standards, there is evidence that they are becoming increasingly capable (Chen 2008). For instance, they compete for international financing and for access to global reserves, not only with other NOCs and IOCs, but also with each other both internationally and domestically (Lewis 2007; Kambara and Howe 2007). A glance at the Forbes annual ranking of the world's biggest companies reveals that the market value of PetroChina (the publicly listed arm of CNPC) is higher than that of any IOC and that the company's profits in 2009 were higher than of any IOC, with the exception of ExxonMobil (Forbes 2010).

The second statist dimension of China's oil security strategy has been dubbed its "going out" strategy - the attempt to secure direct access to equity stakes in upstream projects around the world (Downs 2000). Prior to this, the Chinese government handled the bulk of China's oil import policy. For instance, in May 1995, China negotiated directly with Iran to triple its oil imports to 60,000 barrels per day (b/d). Since they entered the global oil market in 1997, China's NOCs have pursued investment deals all over the globe and in all aspects of the oil industry-for example, exploration, extraction, and refining. Oil imported from Iran's Yadavaran oil field is contingent on Sinopec's developing the oil field itself in conjunction with India's NOC. In 2003, Sinopec signed its first agreement 
with the State Oil Company of Azerbaijan Republic (SOCAR) valued at $\$ 140$ million, joining CNPC in overseas exploration and production projects (Berniker 2003).

The third dimension supports the first two - the use of state diplomatic resources to pave the way for China's NOCs. The establishment of diplomatic relations has underwritten China's overtures to several energy-producing states. For example in 1997, CNPC's bought a 60 percent stake in Kazakhstan's Aktyubinsk Oil Company. As Erica Downs (2000, 16) notes, CNPC was able to beat out competing IOC bids by including a $\$ 320$ million bonus paid directly to the Kazakh government. Bids by Chinese NOCs are often supported by foreign aid from Beijing. For instance, Beijing's purchase of a 40 percent stake in Sudanese oil in 1997 included refinery, railway, and port construction. Importantly, this assistance goes beyond the infrastructure required for the oil industry and can include foreign aid as well as diplomatic assistance on the global stage and in the United Nations Security Council.

\section{Japan's Hybrid Approach}

Japan's experience with the oil crises of the 1970s shattered Tokyo's belief that oil security could be achieved through market strategies alone. Following the crises, it seemed to accept its fate as an importer and used a variety of methods, such as improving energy efficiency through industrial adjustment and moving to alternative energy sources, to provide for energy security. Nevertheless, government actors maintained an active role in the energy sector. In its first display of oil diplomacy, Japan broke with US Middle East policy in order to ensure supplies from OPEC (Yorke 1983). Following the second oil shock, Tokyo developed a mistrust of Western IOCs and began negotiating directly with the governments of oil-producing nations (Eguchi 1980; Fukai 1988). In light of the low oil prices of the 1980s, there was a view in Japanese policy circles that oil security could be ensured through reliance on the global market. After much debate, a hybrid approach emerged that combined market and nonmarket principles (Lesbirel 1988). Japan's hybrid approach is composed of three factors: a stated commitment to a functioning and efficient global oil market, the development of equity oil projects overseas, and, more recently, the use of oil diplomacy to support these aims.

Japan maintains a stated commitment to an energy policy based on market principles. Article 4 of the Basic Act on Energy Policy stresses that "deregulation ... shall be promoted in a manner such that business operators can fully demonstrate their initiative and that such creativity 
and the interests of energy consumers are sufficiently secured, while giving due consideration to the policy objectives in the preceding two articles" (Government of Japan 2002). The final clause is indeed a caveat. Articles 2 and 3 call for Japan to diversify its energy sources by type and import region in an effort to secure stable energy supply, and for Japan to ensure that its energy policy is environmentally sustainable. Japan thus favors markets, as long as they support Japanese energy and environmental security. According to Japan's 2006 energy security strategy, Japan seeks to leverage its comparative advantage in energy efficiency to further reduce its energy intensity and to assist its Asia-Pacific neighbors in this endeavor as well. In doing so, it hopes to avert "stirring up international competitions for natural resources" (ANRE 2006, 11). By promoting conservation at home, Japan seeks to reduce its oil consumption in an era of tight capacity in the global oil market. In this vein, Japan maintains one of the largest strategic petroleum reserves in the world, which, in coordination with other International Energy Agency (IEA) member states, can mitigate the effects of global oil supply disruptions, most recently after Hurricane Katrina. Japan also defends its overseas oil procurement activities in market terms. By ripening conditions for Japanese energy companies in exporting countries, Japan reinforces its "international contribution for the stabilization of the whole world's energy market" (ANRE 2006, 26).

Tokyo has always viewed developing oil overseas through Japanese firms as an integral part of import diversification policy and has relied on state institutions to support this policy (Nemetz, Vertinsky, and Vertinsky 1984-1985). The pursuit of equity oil through the Japan National Oil Company (JNOC) emerged as an extension of Japan's resource diplomacy following the oil shocks. Under the 2006 energy policy Hinomaru, oil is set to jump from 15 percent to 40 percent of imports by 2030 (ANRE 2006). Strategy implementation is led by the Ministry of Economy, Trade, and Industry (METI) and by the Ministry of Foreign Affairs (MOFA). While the former is charged with the formulation of energy policy writ large, the latter is charged with developing the necessary political relationships to diversify sources of oil supply away from the Middle East. Problematically, Japan's state energy sector has suffered a number of setbacks overseas. JNOC posted a \$3 billion loss in 1998 and had debts of more than $\$ 8$ billion by 2001 (PIW 2001; Takahashi 2000). JNOC was disbanded as part of the restructuring of the Japanese state energy sector in 2001. Among other privatization measures adopted in 2004, METI created a new state-owned oil company-the Japan Oil, Gas, and Metals National Corporation (JOGMEC)—and sold its majority shares in Inpex, Japex, and the other major Japanese oil corporations. 
The government is thus no longer directly involved in the actions of Japanese oil companies; rather it simply supports their overseas activities through JOGMEC. The merger of Inpex, Japan's largest oil company, with Teikoku, the third largest, is designed to increase the leverage of these against other players on the international oil market where bigger is better (Glain 2006-2007).

While Japanese oil companies are no longer state owned, they, like China's, rely on state support beyond that provided by JOGMEC. According to MOFA (2004), "Japan is working to strengthen relations with oil exporters, and to improve the investment environment." This aims to encourage Japanese companies to produce oil overseas and to build political relationships with oil-exporting countries. More recently, the statebacked Japan Bank for International Cooperation (JBIC) has focused on acquisitions of overseas resources rather than on development and has, according to the Economist (2009), \$12 billion available. Japan seeks to purchase oil directly from supplier nations at reduced prices in exchange for investment or official development assistance (ODA). For example, in July 1979 officials of the Ministry of International Trade and Industry (MITI) traveled to Iraq to buy oil directly from Baghdad in exchange for $\$ 2$ billion in loans (Klein 1980). This effort to cultivate political relationships endures today and has arguably gained momentum. Problematically, this strategy has traditionally been focused on the Middle East and has been heavily constrained by high costs.

\section{Measuring Diversification}

Diversification is thus common to all three types of energy security strategies and refers to the mix of suppliers of oil. A more diversified import diversification strategy is one that sources oil from several different regions of the world, thereby minimizing the potential for supply disruption. Relying on a single source for oil imports is generally far riskier than importing oil from multiple sources. Having multiple suppliers provides security and reduces vulnerability in cases of temporary or permanent disruption of supply. Should one supplier fall victim to natural disasters, terrorism, war, regime change, or other export-damaging events, importers will only experience minor disruptions to their total supply (Leiby 2007). To ascertain the extent of diversification achieved by three distinct approaches, we look at both the level of diversification and changes in it. A key finding is that China's statist approach has allowed it to diversify its sources of imported oil more quickly than Japan's hybrid approach. In fact, since becoming a net oil importer in 1993, China's sources of imported oil have diversified quite rapidly. Japan's 
overreliance on the Middle East for much of its imported oil has been endemic since 1973.

\section{Methodology}

In the following analysis, we evaluate the oil import diversification strategies of China, Japan, and the United States by providing data on the extent of diversification as measured by the Shannon-Wiener index (SWI). We rely on the BP Statistical Review of World Energy, which divides oil exporters into nine major oil-exporting regions: Asia-Pacific, Central and South America, Eastern and Southern Africa, Europe, former Soviet Union (FSU), Middle East, North Africa, North America (including Mexico), and West Africa. There is arguably some advantage in looking at diversification at the country level, where political and other risks are ultimately located. Nevertheless, the rationale behind our choice of breaking down exporters into nine major oil-exporting regions is that countries located in these regions share certain types of characteristics and risks. For instance, instability in one country in a particular region is likely to affect the risk profile of the entire region, such as in the case of various Middle Eastern and African conflicts that involved several countries. There is also often a diffusion effect related to the spread of populist movements or oil industry nationalizations, as in the case of South America in the 2000s. Countries in Europe and the FSU also bear much resemblance. While Europe is largely politically stable, there has been much uncertainty in the FSU following the breakup of the Soviet Union and ensuing uncertainty during the restructuring of key oil exporters' domestic oil industries.

The Shannon-Wiener index is calculated as follows:

$$
S W I=\sum_{i=1}^{I}-p i \ln (p i),
$$

where $p i$ is the proportion of oil imports from the $i$ th oil-exporting region. The minimum value taken by the index is 0 , where there is only one region from which oil is imported. The SWI rises to the maximum value of 2.2 for 9 equal components (oil-exporting regions). A value closer to 0 indicates low level of diversification, high concentration, and dependence on very few oil-exporting regions that may threaten the security of supply in the event of any sustained interruption. A value closer to 2.2 indicates a high level of diversification, with numerous sources of imported oil, none of which play a dominant role. Such a system can be considered to be reasonably secure in the face of interruption in any particular oilexporting region. 
Results and Analysis

The available data allow for the assessment of the extent of oil import diversification for the United States and Japan between 1973 and 2009, and for China between 1994 and 2009. ${ }^{2}$ Based on Eq. (1) we calculated the SWI for the three countries. Figure 1 shows the SWI applied to the corresponding data.

It is apparent from Figure 1 that there is much contrast in the extent of oil import diversification for the United States, Japan, and China. In particular, as measured by the SWI, the sources of US oil imports have been most diversified, diversification of China's sources of imported oil has improved dramatically since the country became a net oil importer in 1993, and Japan's diversification has been consistently low, with only a slight improvement during the 1980s. ${ }^{3}$ In the following sections, we discuss the findings for each case.

\section{The United States}

While the aim of this article is to explain differences in Japan's and China's oil import diversification, the United States is explored simply to put the Japanese and Chinese efforts in perspective, as it has a welldiversified oil import record. For an oil importer, it is practically impossible to achieve "perfect diversification" or the value of 2.2 for SWI. After all, not all nine oil-exporting regions as conceptualized here are

Figure 1 Oil Import Diversification (SWI) for China, Japan, and the United States (1973-2009)

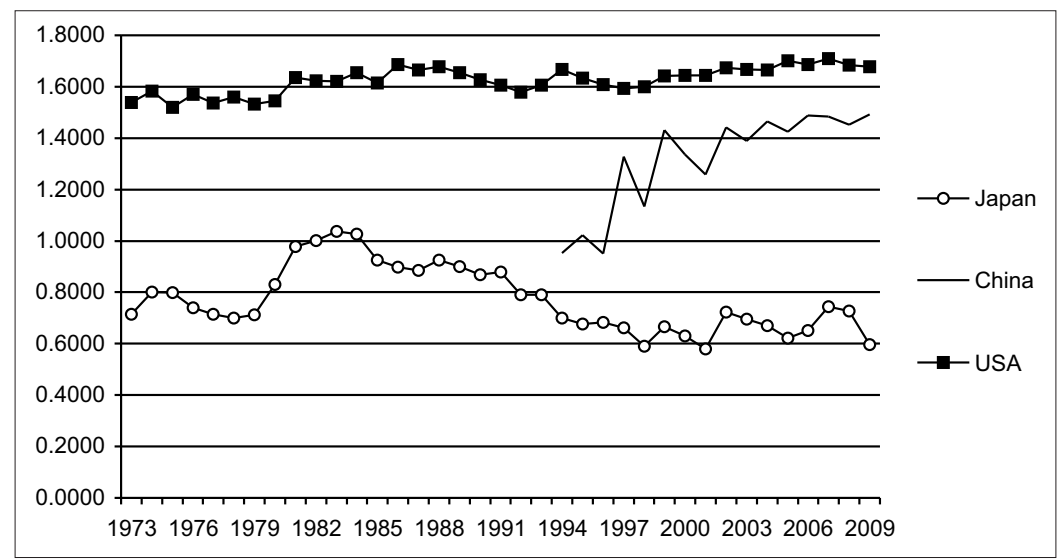

Note: SWI = Shannon-Wiener index. 
equally oil-rich, and they all cannot export equal volumes of oil. For instance, it is impossible for resource-poor Europe or Asia-Pacific to match Middle Eastern oil export volumes. The United States has, however, achieved a very high degree of diversification as conditioned by the global geological distribution of resources. The United States, in this sense, is the benchmark against which Chinese and Japanese efforts may be assessed and the extent of their diversification ascertained.

US oil imports from the Middle East have been limited, and in line with US goals, private Western oil companies have internalized diversification risk and enhanced oil production in regions outside the Middle East. This is unsurprising given that the Middle East has by and large been closed to any substantial investment by private oil companies that supply the United States with much of its imported oil. These companies have instead ventured into hitherto underexplored areas that have welcomed foreign investment. As a consequence, between 1973 and 2009, the United States imported a maximum of 29 percent of its oil from the Middle East (in 1977). The average imports from the Middle East during this period stood at 20 percent. That the Middle Eastern share in total US oil imports has remained steady is a remarkable feat given that US oil imports have more than doubled in volume in the past two decades. As a consequence of low dependence on the Middle East, other regions have provided the bulk of US oil imports (Figure 2). This dependence has been primarily on its neighbors: Canada, Mexico, and Latin America. On average, the United States relied on the Americas for 48 percent of its imported oil during the 1973-2009 period. Strikingly, following the creation of NAFTA in 1993, the share of Canada and Mexico oil imports increased from 14 percent in 1993 to 32 percent in 2009. However, other regions, such as West and North Africa, Europe, and increasingly the FSU, have also played an important role in US oil import diversification. In fact, US oil imports from West and North Africa during this period have rivaled those from the Middle East. As indication of a high degree of oil import diversification, the average US SWI stands at 1.7346 (out of the maximum value of 2.2), with the minimum value of 1.6331 in 1973 and the maximum of 1.8319 in 2007 . The low range between the minimum and the maximum SWI shows a high degree of consistency and constancy in the US diversification efforts.

\section{China}

When it shifted to being a net oil importer in 1993, China was largely reliant on its region (Asia-Pacific) for imported oil. In 1994, 69 percent of China's imported oil originated from the Asia-Pacific region and, as a 
Figure 2 Share of US Oil Imports by Source Region (1973-2009)

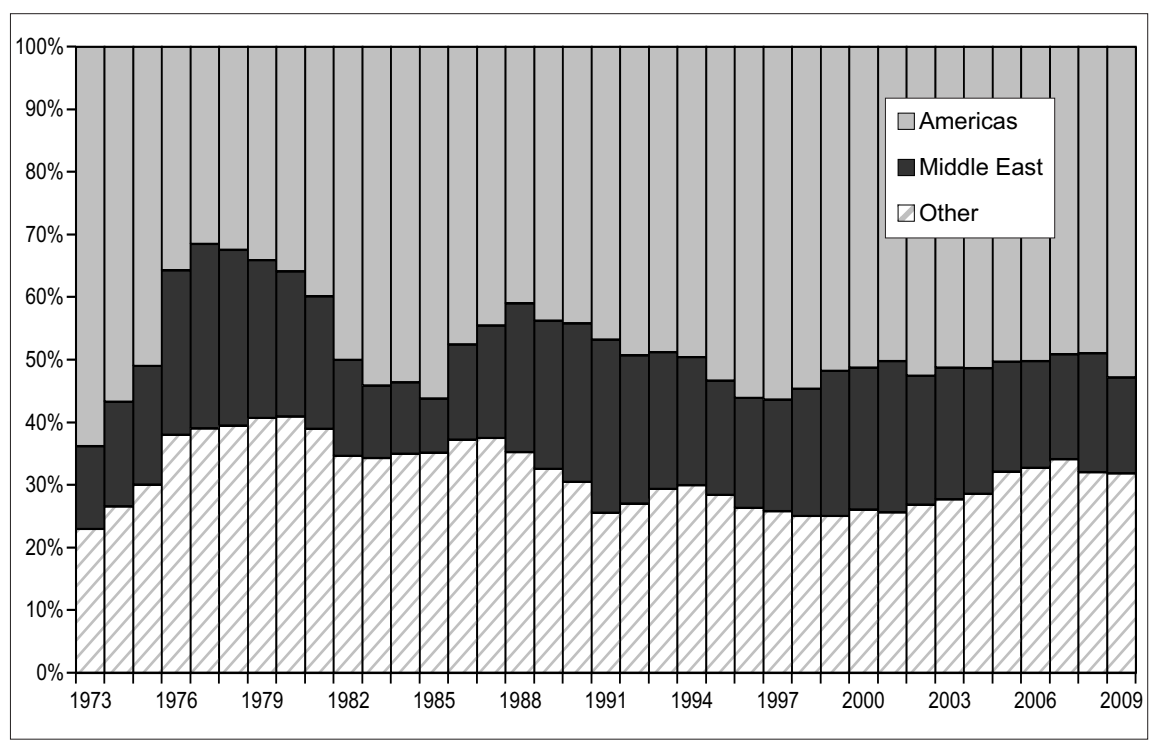

consequence, China's SWI was at relatively low levels during the 19941996 period. As China's thirst for oil increased, it required increasing volumes of imported oil that the region could not accommodate, and it began actively sourcing its supplies from other regions, particularly the Middle East and North Africa, but also from the former Soviet Union and South and Central America (see Figure 3). Consequently, in only five years, from 1994 to 1999, China's oil import diversification profile was transformed from being dominated by one region to a profile that exhibited a high degree of diversification, with three regions (Asia-Pacific, Middle East, and West Africa) each accounting for over 10 percent of imports.

Since 1999, China's oil import volumes have continued to grow by an average 17 percent annually (BP 2010). Given such high increase in import volumes, one would expect an increase in Middle Eastern import share, particularly given that it is the region with most reserves that can be produced at the lowest cost. However, although import volumes from the Middle East increased, their overall share in China's oil imports remained relatively constant and peaked at 43 percent in 2000 . At the same time, China's imports from the resource-poor Asia-Pacific region dropped from 42 percent in 1999 to 15 percent in 2007, the level at which 
Figure 3 Share of China's Oil Imports by Source Region (1994-2009)

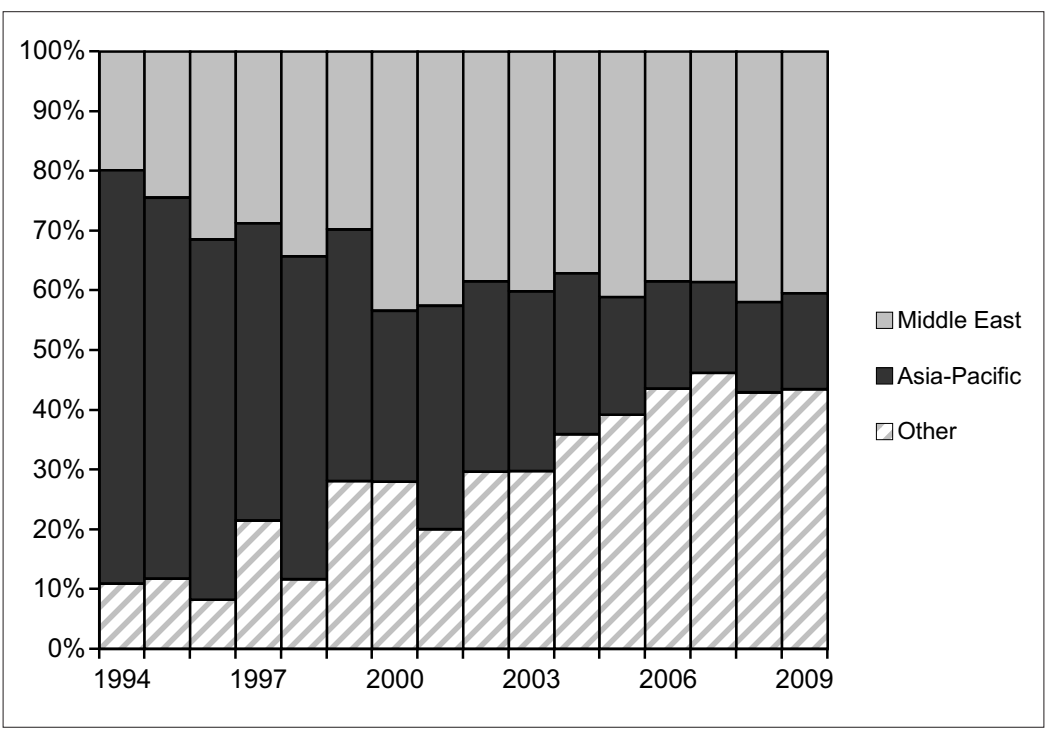

they have remained since (see Figure 3). These declining volumes were replaced by increased imports from various parts of Africa, South America, and the FSU. In 2004, China for the first time imported over 10 percent of its oil from four different regions, a feature that has remained since. Overall, since becoming a net oil importer, China has consistently been able to secure access to additional sources of oil, reflective in the improved SWI. Since 2002, China's SWI has remained at relatively high levels of over 1.5, reaching the peak of 1.7067 in 2009 (Figure 1).

Japan

In contrast to China, Japan is a seasoned oil-importing nation. It is a resource-poor country with negligible domestic oil production. Although Japan imports over 99 percent of its oil requirements, as a consequence of the two oil crises in the 1970s and subsequent conservation, and of substitution and other energy efficiency efforts, the country's oil demand has remained steady throughout the past four decades, with occasional peaks and troughs. Similarly, and surprisingly, given Japan's extremely high dependence on imported oil, the country's oil import diversification effort as measured by SWI was consistently low during the 19732009 period (Figure 1). The average SWI for Japan for that period was 
0.7776, with the maximum value of 1.0416 in 1983 and the minimum of 0.5896 in 2001. The only real, albeit temporary, increase in Japan's diversification effort came at the backdrop of the two oil crises in the 1970s, when the country reduced its oil import dependence on the Middle East from 75 percent in 1978 to 65 percent in 1985. However, by 1995, Japan again imported 75 percent of its oil from the Middle East (Figure 4). In fact, from 1973 until 2009, Japan was reliant on the Middle East for an average 74 percent of its oil imports, peaking at 84.5 percent in 2009 . The Asia-Pacific has been the only other region with a constant doubledigit share in Japan's oil imports up until 2008. However, due to the region's geological constraints, its share dropped from 20 percent in 1997 to as low as 8 percent in 2009 (Figure 4). As a consequence of a recent increase in Middle Eastern and a decrease in Asia-Pacific import shares, in contrast to China's, Japan's SWI has been on a downward trend since 2002. While Japan's recent forays into North and West Africa and the Russian Far East have had diversification of sources of imported oil as their main aim, Japan has been unable to source any more than 6 percent of oil from these regions combined in any single year.

The quantitative analysis we employed in this section helped determine the extent of diversification of sources of imported oil by the United States, Japan, and China. As measured by the SWI the United States has

Figure 4 Share of Japan's Oil Imports by Source Region (1973-2009)

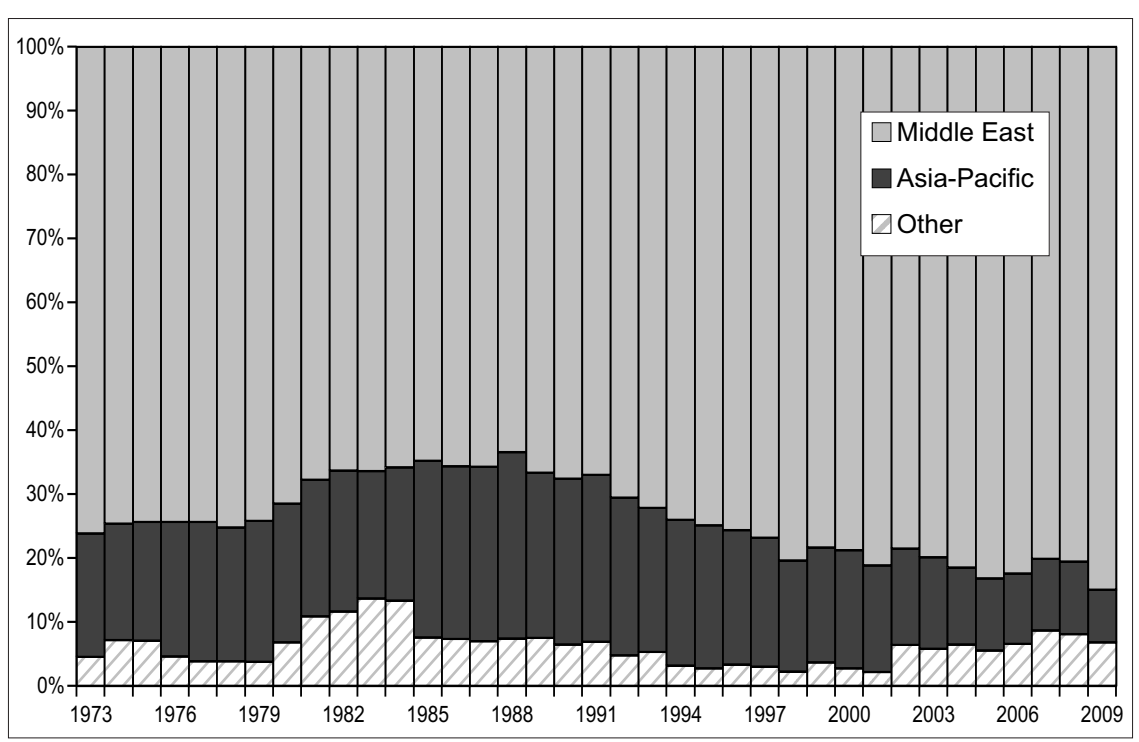


had the most diversified portfolio, as it achieved much more substantial diversification than either Japan or China. Against this benchmark, China's oil imports have become dramatically more diversified since the country became a net importer of oil. By contrast, Japan has remained reliant on the Middle East. This significant divergence in the extent of oil import diversification is striking when considered against the overlaps in their energy security strategies outlined earlier as well as their similar geographic locations. In the following section we revisit the oil security strategies outlined at the beginning of the article to explore actor contingent and structural explanations for this phenomenon.

\section{The Strategy and Geography of Oil Import Diversification}

Why are China's oil imports more diversified than Japan's? What factors, be they situational or policy related, have allowed China to diversify its imports more effectively than Japan, a country that by any measure has a greater incentive to do so because of its high (99 percent) reliance on imported oil? In this section, we explain this phenomenon by exploring the nexus of two levels of analysis: structurally contingent factors such as a state's geographic circumstances, and actor contingent factors such as a state's energy security strategy and the tools available to implement it. These two factors interact to affect a state's willingness and capacity to diversify its oil imports.

\section{Geography}

However much a state may want to diversify import source, it cannot overcome its fixed position on the map; geography can support or constrain diversification efforts and in turn affect relative costs. While China is located in the relatively oil-poor Asia-Pacific region, its geographic location favors a diversification strategy. Aside from its considerable onshore oil reserves, China is contiguous to the resource-rich Russian Far East as well as to the reserve bases of Central Asia. Russia is a particularly promising alternative to the Middle East because of its impressive resource base, advanced production, and sophisticated oil industry as well as its relative political stability. A further benefit provided by China's geographic position is that it can import oil in multiple ways. Russian and Central Asian imports can travel by pipeline, which are nominally more secure, although more expensive, than seaborne imports because they are not vulnerable to blockade. Clearly the distribution of China's economic activity, concentrated on the East Coast, creates a predisposi- 
tion for seaborne oil imports. However, China's distrust of US-policed sea lanes acts as an incentive for investment in contiguous areas (Downs 2000). This has served to keep imports from the Middle East at a peak of 43 percent in 2000 . Nevertheless, China's vulnerability to strategic blockade has increased concomitant with rising imports from Africa and the Americas. Currently, 80 percent of China's oil imports travel through the Malacca Strait, which in the event of a conflict could easily be blockaded by US naval forces. According to some this concern has underwritten a more expansive operational sphere for the People's Liberation Army Navy (Collins, et al. 2008; Lanteigne 2008). Chinese policymakers clearly view oil as a strategic commodity that must be protected. China's pursuit of pipeline projects through Russia, Central Asia, and Southeast Asia to the Middle East adds security.

However, geographic proximity to Central Asian and Russian fields has not necessarily been translated to more affordable oil. Problematically, the current infrastructure to import oil from Central Asia and Russia is still under development. China's willingness to pay a premium to import Siberian oil appears to be considerable. In 2001, Moscow and Beijing agreed on a 2,300-kilometer pipeline from Angarsk to Daqing that would transport 20-30 million tonnes of crude per year over twentyfive years. However, construction stalled because of the ramifications surrounding Yukos and because of the appeal of Japan's offer to build a pipeline to Nakhodka that would open Siberia to global markets (Goldstein and Kozyrev 2006; Vivoda 2008). Throughout the entire saga over the Siberian pipeline network, China has been importing oil to Daqing from Siberia by rail. In 2009, China imported 539,000 b/d from Central Asia and Russia (BP 2010). According to some, however, Beijing's strategic mistrust of Russia will serve as a cap on China's reliance on Russian oil imports, particularly given Russia's willingness to use its energy sector for political purposes as witnessed against Ukraine (Ziegler 2010).

China and its contiguous neighbors Kazakhstan, Burma, and Russia have committed US $\$ 23.9$ billion to build three pipelines that will deliver 1 million b/d to China from Kazakhstan and Russia, and 240,000 b/d of Middle Eastern oil through Burma, once they are fully operational. ${ }^{4}$ The prohibitive price and in some cases dubious feasibility of these pipelines are further evidence of the premium Beijing is prepared to pay for secure oil imports. For instance, plans are under way to build an oil pipeline that mirrors the West-East gas pipeline to transport Central Asian oil to the Yangtze Delta. In 2004, China and Kazakhstan announced they would construct a 2,800-kilometer oil pipeline from Western Kazakhstan to Xin- 
jiang province. According to some analysts, the length of the pipeline combined with its small capacity belies sound economic judgment (Chow and Hendrix 2010, 37), although current plans are to link the pipeline with the giant Kashagan oil field north of the Caspian Sea. In any event, China is paying a high premium to secure future access to just under 0.5 million b/d of oil from the former Soviet Union.

Japan by contrast is an island state in an oil-poor region. The paucity of domestic reserves and the relative low cost of seaborne trade underwrote the beginnings of Japan's reliance on oil imports from the Middle East. The Cold War, low global oil prices, and the high cost of pipelines have militated against higher oil imports from Russia. The dramatic rise in global oil prices in 2004 exposed Japan's continued reliance on Middle East oil and sparked a renewed interest in import diversification. In this context, gaining pipeline access to Siberian oil became more appealing, and Japan's oil imports from the FSU, mainly from Sakhalin Island, increased from 0.04 percent to 4.18 percent of total oil imports between 1999 and 2009 (BP 2010). The most important geographic handicap on Japan is its location in a high-demand region of the world. According to one analyst, scarce energy supplies in the Asia-Pacific have already led to hoarding behavior ahead of expected surges in demand, such as before the winter months set in. Thus, Japan faces stiff competition for supplies in light of rising demand from China, India, South Korea, and Southeast Asia despite the decline of oil in its energy mix (Yokobori 2005).

Despite being in the same region as China, Japan's geographic position raises the costs of import diversification. Seaborne transportation and refining infrastructure for Middle East crude are well developed, which reinforces Japan's reliance. Japan's state-owned tanker fleet provides a degree of import security by militating against losing oil to alternative buyers and by placing the security of these vessels on Japan's security agenda. In contrast, 90 percent of the oil China imports arrives on foreign-owned oil tankers. There is thus a concerted effort by Beijing to dramatically expand its tanker fleet to a capacity of 75 million tons. Interestingly, Japan, which has supertanker capacity equal to 80 percent of its oil imports, is cited as an ideal case (Xinhua Daily 2006). Japan's seaborne infrastructure could assist imports from regions that feature in its Hinomaru policy, such as South and Central America, although Japan's refineries are currently unable to process Venezuelan heavy crude. Landbased transportation in East Asia remains underdeveloped. The prohibitive cost of the East Siberian-Pacific Ocean (ESPO) pipeline, close to 
$\$ 15$ billion, is a testament to Japan's (and China's) willingness to gain access to Siberian oil resources (Goldstein and Kozyrev 2006). Likewise, Japan's overtures to Central Asia contain a high degree of infrastructure spending designed to increase production in order to lower global prices. Direct access to reserves in landlocked Central Asia is impossible. This geographic constraint - the poor availability of oil specific to Japancreates an incentive for a market-oriented response that relies on Middle East imports.

\section{Strategy}

The geographic constraints and opportunities noted earlier affect state energy security strategies and taken together explain why China's oil imports are more diversified than Japan's. Three dimensions of China's oil import diversification strategy allow it to take advantage of its geography. First, Beijing has the willingness to pursue diversification despite the diplomatic and financial costs imposed by geography. Second, Beijing can afford to pay these inflated costs. Third, the blend of commercial and state orientation of China's NOCs has resulted in activities of a sufficient scale to increase the diversification of imports.

In the first instance, Beijing is willing to incur international opprobrium in the pursuit of oil import diversification. This is partly caused by circumstances of the early stages of China's "going out" strategy. Beijing limited the activities of its NOCs to areas where they would not confront competition by more efficient IOCs, typically in states isolated by US or international sanctions. Targeting these marginalized producers allowed China's NOCs to develop a niche market at a time when they were relative newcomers to the international oil market. For example, China leaped at the opportunity to invest in Sudan's oil industry following the exodus of IOCs in 1996. China has provided billions of dollars in aid and political assistance to Khartoum, particularly in light of the conflict in Darfur. This political assistance facilitated entry into the Sudanese oil industry, and recent developments suggest China's primary preoccupation remains with the development of oil. It appears that Beijing is prepared to recognize the new independence of oil-rich Southern Sudan after its succession, reversing decades of Chinese policy vis-à-vis the global territorial status quo (ICG 2008). Likewise, Beijing and Tehran agreed on a twentyfive-year liquefied natural gas deal worth over $\$ 100$ billion, as well as development of its Azedegan oil field (Afrasiabi 2004). Beijing's willingness to weather international, and particularly US, criticism of its relationship with these regimes supports its diversification strategy. 
Second, China can afford to pay the costs needed to capitalize on geographic opportunities to import oil from a greater number of producers. While its NOCs received a capital injection following their initial public offerings in 2001, the Chinese state continues to subsidize their overseas operations in a number of ways. In addition to direct financial support, NOCs can offer low-interest loans from the Chinese Development Bank and the China Export-Import (Exim) Bank as well as lines of credit. Lowinterest loans were integral in financing CNOOC's bid for Unocal in 2005, and lines of credit have been extended to Brazil, Russia, Venezuela, and Kazakhstan to help finance oil production in those countries. Beijing typically insists that these arrangements include some guarantee of oil exports to China (Richardson 2009). This financial support also extends to political aims. In 2004, China Exim Bank extended a \$2 billion soft loan to Angola to finance Chinese infrastructure projects there, and the bank has also been part of upstream investments in Nigeria, Congo, and Sudan. As a sign of growing Chinese interest in Canadian resources, the China Investment Corporation, which manages \$300 billion of China's foreign exchange reserves, recently established an office in Toronto, the mining and energy capital of North America (Hoffman and Perkins 2011). China's approach has raised the ire not only of the United States, but also of other states with NOCs, such as India, that are competing for upstream access in oil-producing countries (Evans and Downs 2006). Furthermore, it is likely that China has paid a significant premium for oil produced under these conditions. Low global prices during the 1990s, when China's "going out" strategy began, may partly explain its success in outbidding IOCs when they came into direct competition. China's diversification strategy is supported not just by the relationship between the NOCs and the state, but also by the growing wealth of the Chinese state.

Finally, the sheer scope of NOC activities has supported China's import diversification strategy; it has limited China's reliance on Middle East oil to approximately 40 percent of imports. The NOCs are rent-seeking entities, which are partially privately owned, but they are also tools of energy security policy. By pursuing upstream oil projects worldwide, the NOCs have improved their performance as companies, while producing more oil for Chinese consumption. It is important to note that the bulk of oil produced overseas by Chinese NOCs is sold on the world market; it is not sent directly to China (ICG 2008). Rather, oil is transported by tanker and bought and sold on the spot market. Theoretically speaking however, in the event of a supply disruption, this oil could be redirected to China. Whether this would actually result in lower prices for 
Chinese consumers remains subject to debate (Downs 2004). In any event, the fact that NOC investments are spread worldwide provides security against supply disruption in a given region. The share of noncontiguous regions in China's overall oil imports has increased considerably in the last decade, and oil diplomacy has helped China secure much-needed oil supplies from South America, North Africa, and West Africa. The overall share of these three regions in China's oil imports rose from just under 5 percent in 2001 to over 27 percent in 2009, while the overall import volumes from these three regions increased tenfold during the same period (BP 2010).

The scale of this effort is as much a product of the NOCs' commercial interest as it is a product of government directive. This is illustrated by the fact that Beijing's efforts are no longer limited to international pariah states. Beijing has enhanced diplomatic, economic, and military ties with Middle Eastern states in the pursuit of oil imports. President Jiang Zemin's visits to Libya and Iran in April 2002 coincided with the decision by governments in Libya, Iran, Iraq, and Kuwait to increase their domestic production capacity (Xu 2002). In 2009, China signed a $\$ 16$ billion investment deal to raise oil output in Venezuela. The investment by China, spread over three years, would go toward developing heavy oil resources in the Orinoco River belt and will increase China's imports from Venezuela (Wan 2009). Beijing and Ottawa signed the Statement on Energy Cooperation in the Twenty-first Century in 2005 and, despite the southward orientation of existing transportation infrastructure and amid several false starts, Chinese entities remain interested in Alberta's tar sands (Constantin 2008). PetroChina paid $\$ 1.9$ billion for a 60 percent stake in Athabasca Oil Sands Corporation, a deal that includes the construction of upgrade facilities in Alberta, which would reduce Canadian reliance on US refineries (McCarthy 2009).

By contrast, Japan's oil import diversification strategy confronts a number of constraints. Like China, Japan has used political influence to curry favor with oil-exporting nations, but this has most often been limited to concerns about price and availability rather than aimed at bringing new oil production online. One of the most important constraints of the political dimension of Japanese diversification policy is Japan's relationship with the United States. For example, in 2006, Washington pressed Tokyo to reduce Inpex's stake in the enormous Azedegan oil field from 75 percent to 10 percent in light of concerns about Iran's nuclear weapons program. Japanese firms recently exited the project completely. Unlike China, Japan is constrained in its ability to import oil from regimes that 
are at odds with the United States, such as Iran or Sudan. This has not always been the case. As noted earlier, Japan broke with US Middle East policy in the wake of the first oil crisis. More recently, Japan has made several investments in Venezuela's Orinoco belt. While Venezuela remains unpopular in Washington, this could be seen as a safe investment by Tokyo given the scale of Venezuela's oil exports to the United States.

Also in contrast to China, Japan's own "going out" strategy-its Hinomaru oil policy - has suffered a number of policy failures despite being a component of Japanese energy security strategy since the oil crises. Equity oil has only ever provided half the oil expected by MITI/ METI. For instance, the targets for equity oil's share of total imports was 30 percent in FY 2000 but amounted to a mere 13.2 percent of imports (Drifte 2002). Japan's most successful equity arrangement was the Arabian Oil Company (AOC), which operated the offshore section of the neutral zones between Kuwait and Saudi Arabia. It produced 300,000 b/d, roughly half of Japan's equity production (Manning 2000). However, in 2000, the AOC lost its concession after it refused to succumb to Saudi demands to increase its investment in the project (Shaoul 2005). The AOC's concession of the Kuwait Neutral Zone operation now receives only 50,000 b/d under a joint development agreement (EIA 2008).

Japan's track record through the 1990s indicates a commitment to diversify energy type rather than import source. According to data compiled by S. Hayden Lesbirel (2004, 4-6), Japan is now less reliant on the Middle East for its total energy consumption, despite being more dependent than ever on Middle East oil imports. This was driven by a move toward liquefied natural gas imported from the Asia-Pacific region. Japanese entities were also not as active overseas as their Chinese counterparts during the period of relatively cheap oil during the 1990s. While Tokyo was rhetorically committed to the idea of owning a greater percentage of the oil in Japan, it may be that Japan is unwilling to pay the premium Beijing has to produce oil in strategically vital states. Japan's efforts remained focused primarily in the Middle East, which does not contribute to the diversification of oil import source.

However, it appears that oil import diversification, embodied by the Hinomaru policy, has undergone a renaissance under the 2006 Energy White Paper, although it remains to be seen whether it will result in greater import diversification. Like in China, state-supported overtures include a range of incentives. For example, Japan's recent deal with Venezuela included a feasibility study of the Orinoco oil belt, an agreement on LNG development, as well as loans from the Japan Bank for In- 
ternational Cooperation and others for the upgrade of two refineries (Mogi 2009). The deal also included financing for railway projects, housing, and highway construction, possibly from a $\$ 3.5$ billion line of credit extended in 2007 (BBC News 2009). Japan has also attempted to build on its political capital in Central Asia, developed as a long-standing aid donor to the region, to improve the region's pipeline infrastructure (Len 2005). Japan has engaged Central Asian states with the aim of developing a sophisticated pipeline system from the landlocked region to global markets. This involves providing technical assistance and investment and engaging all regional governments in dialogue (Fukushima 2007). These efforts may result in lower oil prices and therefore support Japanese energy security, but geographic constraints nevertheless prevent the direct import of oil from Central Asia to Japan and thus limit the ultimate level of diversification possible.

\section{Findings and Analysis}

In this article, we have shown that China's oil imports are more diversified than Japan's and that they have become more diversified over time. This is due to a variety of factors, some of which are unique to China, others that are not. As measured by the SWI, diversification of China's sources of imported oil has improved dramatically since the country became a net oil importer in 1993, and Japan's diversification has been consistently low, with only a slight increase during the 1980s. The analysis shows that China's statist approach to the security of energy supply has achieved a more diversified portfolio of oil imports than Japan's hybrid approach. China's approach is supported by several geographic conditions. China's geographic location has allowed it to directly import oil from Central Asian states and Russia, and its onshore reserves kept its reliance on the Middle East moderate. Japan by contrast developed a reliance on seaborne Middle East oil and is now, unsuccessfully, trying to move away from it. Japan continues to rely on the Middle East for over 80 percent of its oil imports. This appears to have been a deliberate move in the context of the relatively low prices of the 1990s.

Import diversification is an energy security strategy that rubs up against other foreign policy priorities. China's foreign policy independence and its well-financed state-backed NOCs have permitted it to import oil from a variety of non-Middle Eastern sources. By contrast, Japan, because of its alliance with the United States has, on more than one occasion, undermined its efforts to diversify its import sources. As a far more independent power, China has been able to pursue diversification while weath- 
ering international criticism for its deepening relationships with pariah states around the world. Interestingly, the statist dimension of Japan's diversification policy has undergone a renaissance in recent years, but it is unlikely that Japan is able to pay the premiums for import security that China has been paying. Ultimately, China's willingness to pay more to circumvent US-policed sea lanes or to outbid IOCs may be a function of the strategic lens through which it perceives energy security issues.

Whether China's success will endure is unknown. It is likely that Chinese reliance on the Middle East will increase in the medium term. While the Middle East produces 30 percent of total global oil production, approximately 57 percent of the world's remaining oil reserves are located in the region (BP 2010). This implies that the Middle East will play a more important role as an oil-producing and oil-exporting region and that the largest oil importers, particularly the United States and China, may not be able to maintain their rate of diversification indefinitely. In any event, it is clear that China is paying relatively more than Japan to diversify its oil imports. Over the longer term, Chinese billions may be better spent on energy efficiency and demand management initiatives, particularly in the transportation sector, rather than on the pursuit of oil from across the globe in order to fuel its growing addiction.

Japan's efforts to diversify will likely continue to fail. It simply does not have the capital to compete with Chinese NOCs. In 2009, Japan's total government debt, or the borrowing to cover all past budget deficits, was almost 200 percent of GDP. The mountainous debt reflects years of slow economic growth, many stimulus plans, an aging society, and the impact of the global recession (Samuelson 2009). Given that Japan has never had a diversified oil import portfolio, it may be wiser for Tokyo to direct precious finances into paying off government debt. Tokyo is also unable to nurture cozy political relationships with oil-exporting states regardless of their political allegiances. If Japan's Hinomaru policy mirrored that of China, it is unlikely that the Japanese electorate, or its US ally, would be comfortable with Japanese support of pariah regimes such as Sudan and Iran.

It is worth considering the implications of these findings for SinoJapanese energy relations, since their energy security strategies are seen to be competitive. At minimum, this competition has raised the costs of oil imports for both by delaying the development of regional infrastructure, arguably exacerbating both states' energy insecurity. For example, some argue that Tokyo's original impetus for participation in the Azedegan project was to gain a renewed foothold in the Middle East following Chinese gains there; the loss of the stake was seen in zero-sum terms (Shaoul 2005). Instead, Japan's decision to exit the project due to US 
sanctions simply delayed the completion of the project. Likewise, the competition over the route of Russian oil pipelines has developed a soap opera-like quality. The central impact of the ever shifting pipeline routes has been to delay a final plan and to raise costs through expensive stopgap measures such as China's oil imports by rail. Finally, the dispute over gas and oil rights in the East China Sea has delayed full production at the Chunxiao gas fields (Manicom 2008). Japan contested China's right to produce resources in the area, and on several occasions China has halted development of the fields for diplomatic purposes, which has delayed full production.

Both states' energy interests could be achieved at lower cost if they could cooperate. Certainly, there is little benefit to Japan of continuing to compete against China for access to global reserves. Japan effectively needs Chinese acquiescence to gain direct access to Central Asian oil, while China continues to need assistance in improving energy efficiency. Japan is the most energy-efficient country in the world with its energy efficiency enhanced by nearly 50 percent between 1980 and 2006 (Masaki 2006). Given that increased energy efficiency is nominally a cornerstone of China's energy security strategy, cooperation is a possibility (State Council 2007). Cooperating with China for access to global resources, in exchange for assistance with energy efficiency technologies, should have resonance in Tokyo. This could lead to a way out of the zero-sum perspective in a region where there is little tangible cooperation on energy security (Liao 2009; Vivoda 2010a).

One of our key findings - that oil diversification is not only a function of state policy but also a function of a state's geography-may seem unremarkable. Indeed, we have not attempted to comment on the relative weight of the two factors, nor have we explored the conditions under which one factor matters more or less. What can be said is that geography is a barrier to greater import diversification, but not one that is uniform across all states. China has been able to achieve greater diversification at a greater cost, largely because of its geographic location. The costs to Japan of attempting to overcome its geographic situation led leaders in Tokyo to pursue other strategies of energy security, rather than oil import diversification. Interestingly, the renaissance of oil diplomacy in Japanese energy security strategy in recent years may be a function of the perceived politicization of energy markets. Problematically for Japan, this strategy continues to come up against the costs associated with geographic constraints and its alliance with the United States.

While the case of the United States was used to illustrate an example of a well-diversified oil importer, the analysis raises some interesting 
areas for future research. The United States is more diversified than either Japan or China yet does not employ a distinct government-directed diversification policy. There is a certain irony here that provides the basis for future inquiries into the relationship between state energy security strategies and policy outcomes.

Vlado Vivoda is a research fellow at the Griffith Asia Institute at Griffith University, Brisbane, Australia. He has published a book on bargaining in the contemporary international oil industry, along with numerous peer-reviewed articles on energy security-related issues in the the Australian Journal of International Affairs and New Political Economy, and in specialist journals, including Resources Policy, Energy Policy, and the International Journal of Global Energy Issues. His most recent research has focused on energy security in the Asia-Pacific region.

James Manicom is a Social Sciences and Humanities Research Council (SSHRC) postdoctoral fellow at the Balsillie School of International Affairs in Waterloo, Canada. His published works have appeared in Pacific Affairs, Pacific Review, Australian Journal of International Affairs, and Contemporary Southeast Asia. He is indebted to the SSHRC of Canada for support.

\section{Notes}

An earlier version of this article was presented at the 2010 annual meeting of the International Studies Association in New Orleans. Comments are welcome at v.vivoda@griffith.edu.au. The authors would like to thank Claire Jones from BP for providing historical oil import data for China, Japan, and the United States, and the editor and two anonymous reviewers for useful comments on previous drafts.

1. We thank the editor at JEAS for this point.

2. BP's Statistical Review of World Energy started breaking down the sources of China's imported oil from 1994. Although China became a net oil importer in 1993, for data consistency, we do not use data that could have been obtained from other sources for 1993. In addition, although China has imported oil for decades, we only focus on the period during which China has been a net oil importer. This was a conscious choice, as both Japan and the United States were net oil importers throughout the 1973-2009 period. Consequently, comparing the extent of diversification of sources of imported oil between net oil importers (Japan and the United States) and a net oil exporter, China (prior to 1993), would make the comparison less rigorous.

3. The findings are replicated when we consider the Herfingdahl-Hirschmann index (HHI) of market concentration rather than the SWI. The correlation between the two indices was found to be almost perfectly inverse $(r=-0.991$, $r^{2}=0.982$ ) and statistically significant at the 0.01 level. According to this correlation coefficient, a greater SWI is related to a lower HHI, and vice versa. Thus, the HHI generated results consistent with those obtained with the SWI.

4. Based on authors' own calculations. 


\section{References}

Afrasiabi, Kavah L. 2004. "China Rocks the Geopolitical Boat with Iran Oil Deals." Asia Times Online, November 4.

Alhajji, Anas F. 2007. "What Is Energy Security? Definitions and Concepts." Middle East Economic Survey 50, 45 (November 5).

Andrews-Speed, Philip, Xuanli Liao, and Roland Dannreuther. 2002. "The Strategic Implications of China's Energy Needs.” Adelphi Paper No. 346. New York: Oxford University Press.

ANRE (Agency for Natural Resources and Energy). 2006. New National Energy Strategy. Tokyo: Ministry of Economy, Trade and Industry.

BBC News. 2009. "Japan and Venezuela Trade Energy." Available at http://news .bbc.co.uk/go/pr/fr/-/2/hi/asia-pacific/7986905.stm. April 7 (accessed November 11, 2010).

Berniker, Mark. 2003. "China's Hunger for Central Asian Energy.” Asia Times Online. June 11.

BP (British Petroleum). 2010. BP Statistical Review of World Energy 2010. London: British Petroleum.

Calder, Kent E. 1996. Asia's Deadly Triangle: How Arms, Energy and Growth Threaten to Destablize Asia Pacific. London: Nicholas Brealey Publishing.

Chen, Shaofeng. 2008. "Motivations Behind China's Foreign Oil Quest: A Perspective from the Chinese Government and the Oil Companies." Journal of Chinese Political Science 13, 1: 79-104.

Chow, Edward C., and Leigh E. Hendrix. 2010. "Central Asia's Pipelines: Field of Dreams and Reality." Pipeline Politics in Asia, NBR Special Report No. 23 (September): 29-42.

Collins, Gabriel B., Andrew E. Erickson, Lyle J. Goldstein, and William S. Murray, eds. 2008. China's Energy Security Strategy: The Impact on Beijing's Maritime Policies. Annapolis: Naval Institute Press.

Constantin, Christian. 2005. "China's Conception of Energy Security, Sources and International Impacts." Centre of International Relations (UBC) Working Paper No. 43 (March).

- 2008. "China's Energy Policy and Energy Cooperation: Opportunities and Challenges for Canada." CIC Preliminary Paper (July).

Deutch, John, James R. Schlesinger, and David G. Victor. 2006. "National Security Consequences of U.S. Oil Dependency." Council of Foreign Relations, Independent Task Force Report No. 58.

Downs, Erica S. 2000. China's Quest for Energy Security. Santa Monica: RAND.

- 2004. "The Chinese Energy Security Debate." China Quarterly 177: $21-41$.

- 2008. "China's 'New’ Energy Administration.” China Business Review (November-December): 42-45.

Drifte, Richard. 2002. "Japan's Energy Policy in Asia: Cooperation, Competition, Territorial Disputes." CEPMLP Internet Journal 11, 3.

Economist. 2009. "Raising the Stakes," April 8.

Eguchi, Yujiro. 1980. “Japanese Energy Policy.” International Affairs 56, 2: 263279. 
EIA (Energy Information Administration). 2008. "Japan: Country Analysis Brief." US Department of Energy. Available at www.eia.doe.gov/emeu/ cabs/Japan/Full.html (accessed April 17, 2010).

Evans, Peter C., and Erica S. Downs. 2006. "Untangling China's Quest for Oil through State-Backed Financial Deals." Brookings Institution Policy Brief No. 154. Washington, DC: Brookings Institution.

Forbes. 2010. "The Global 2000: The World's Leading Companies," April 21.

Fried, Edward R., and Philip H. Trezise. 1993. Oil Security: Retrospect and Prospect. Washington, DC: Brookings Institution.

Friedberg, Aaron L. 2006. “'Going Out': China's Pursuit of Natural Resources and Implications for the PRC's Grand Strategy." NBR Analysis 17, 3: 5-34.

Fukai, Shigeko. 1988, “Japan's Energy Policy.” Current History 87, 528: 169-184.

Fukushima, Akiko. 2007. “'Central Asia + Japan': The Second Tokyo Dialogue Chairperson's Summary." Available at www.mofa.go.jp/region/europe/ dialogue/summary0701.html (accessed May 11, 2010).

Gilpin, Robert. 1975. US Power and the Multinational Corporation. New York: Basic Books.

Glain, Stephen. 2006-2007. “The Next Big Deal.” Newsweek, DecemberFebruary.

Goldstein, Lyle, and Vitaly Kozyrev. 2006. "China, Japan and the Scramble for Siberia." Survival 48, 1: 163-178.

Government of Japan. 2002. "Basic Act on Energy Policy.” Act No. 71, June 14.

Herberg, Mikkal E. 2004. "Asia's Energy Insecurity: Cooperation or Conflict?" In Strategic Asia 2004-05: Confronting Terrorism in the Pursuit of Power, ed. Ashley J. Tellis and Michael Wills, 339-377. Seattle: National Bureau of Asian Research.

Hoffman, Andy, and Tara Perkins. 2011. "China's Sovereign Wealth Fund Sets Up in Toronto." Globe and Mail, January 12.

ICG (International Crisis Group). 2008. "China's Thirst for Oil.” Asia Report No. 153.

Kambara, Tatsu, and Christopher Howe. 2007. China and the Global Energy Crisis: Development and Prospects for China's Oil and Natural Gas. Cheltenham, UK: Edward Elgar.

Klein, Donald W. 1980. "Japan 1979: The Second Oil Crisis.” Asian Survey 20, 1: 42-52.

Koike, Masanari, Gento Moji, and Waleed H. Albedaiwi. 2008. "Overseas OilDevelopment Policy of Resource-Poor Countries: A Case Study from Japan." Energy Policy 36, 5: 1767-1775.

Kong, Bo. 2009. "China's Energy Decision-Making: Becoming More Like the United States?" Journal of Contemporary China 18, 62: 789-812.

Kreft, Heinrich. 2006. “China's Energy Security Conundrum.” Korean Journal of Defense Analysis 18, 3: 107-120.

Lai, Hongyi. 2007. "China's Oil Diplomacy: Is It a Global Security Threat?" Third World Quarterly 28, 3: 519-537.

Lanteigne, Marc. 2008. "China's Maritime Security and the "Malacca Dilemma."” Asian Security 4, 2: 143-161. 
Lee, Pak K. 2005. "China's Quest for Oil Security: Oil (Wars) in the Pipeline?" Pacific Review 18, 2: 265-301.

Leiby, Paul N. 2007. "Estimating the Energy Security Benefits of Reduced US Oil Imports." Oak Ridge National Laboratory (July 23).

Len, Christopher. 2005. “Japan's Central Asian Diplomacy: Motivations, Implications and Prospects for the Region." China and Eurasia Forum Quarterly 3, 3: 127-149.

Lesbirel, S. Hayden. 1988. "The Political Economy of Substitution Policy: Japan's Response to Lower Oil Prices." Pacific Affairs 61, 2: 285-302.

—. 2004. "Diversification and Energy Security Risks: The Japanese Case." Japanese Journal of Political Science 5, 1: 1-22.

Lester, Richard, and Edward Steinfeld. 2006. "China's Energy Policy: Is Anybody Really Calling the Shots?" Industrial Performance Center Working Paper Series. Cambridge: Massachusetts Institute of Technology.

Lewis, Stephen W. 2007. "Chinese NOCs and World Energy Markets: CNPC, Sinopec and CNOOC." In The Changing Role of National Oil Companies in International Energy Markets, Japan Petroleum Energy Center and the James A. Baker III Insititute for Public Policy.

Liao, Xuanli. 2007. "The Petroleum Factor in Sino-Japanese Relations: Beyond Energy Cooperation." International Relations of the Asia-Pacific 7, 1: $23-46$.

- 2009. "Perceptions and Strategies on Energy Security: The Case of China and Japan." In Energy and Security Cooperation in Asia: Challenges and Prospects, ed. Christopher Len and Alvin Chew, 105-120. Stockholm: Institute for Security and Development Policy.

Manicom, James. 2008. "Sino-Japanese Cooperation in the East China Sea: Limitations and Prospects." Contemporary Southeast Asia 30, 3: 455-478.

Manning, Robert A. 2000. The Asian Energy Factor: Myths and Dilemmas of Energy, Security and the Pacific Future. New York: Palgrave.

Masaki, Hisane. 2006. “Japan's New Energy Strategy.” Asia Times Online, January 13.

McCarthy, Shaun. 2009. "China's Move into Oil Sands Irks Washington.” Globe and Mail, September 1.

Meiden, Michal, Philip Andrews-Speed, and Ma Xin. 2009. "Shaping China's Energy Policy: Actors and Processes." Journal of Contemporary China 18, 61: 591-616.

Mitchell, John, and Glada Lahn. 2007. “Oil for Asia.” Energy, Environment and Development Programme Briefing Paper. London: Chatham House.

MOFA (Ministry of Foreign Affairs). 2004. "Strategy and Approaches of Japan's Energy Diplomacy" (April).

Mogi, Chikako. 2009. "Japan, Venezuela Sign Broad Oil, Gas Cooperation." Reuters, April 6.

Myers Jaffe, Amy, and Ronald Soligo. 2007. "The International Oil Companies." Paper prepared in conjunction with an energy study sponsored by Japan Petroleum Energy Center and The James A. Baker III Institute for Public Policy, Rice University, November. 
Neff, Thomas L. 1997. "Improving Energy Security in Pacific Asia: Diversification and Risk Reduction for Fossil and Nuclear Fuels." Commissioned by the Pacific Asia Regional Energy Security (PARES) Project, December.

Nemetz, Peter N., Ilan Vertinsky, and Patricia N. Vertinsky. 1984-1985. "Japan's Energy Strategy at the Crossroads." Pacific Affairs 57, 4: 553-576.

NEPDG (National Energy Policy Development Group). 2001. National Energy Policy. Washington, DC: NEPDG.

Noreng, Øystein. 2002. Crude Power: Politics and the Oil Market. London: I. B. Tauris.

PIW (Petroleum Intelligence Weekly). 2001. “JNOC's Demise Leaves Mideast Assets in Limbo" August 6.

Richardson, Michael. 2009. "China Closing Energy Deals While Oil Is Cheap." Japan Times, May 29.

Salameh, Mamdouh G. 2003. "The New Frontiers for the United States Energy Security in the 21st Century." Applied Energy 76, 1: 135-144.

Samuelson, Robert J. 2009. "Up Against a Wall of Debt: How Much Can Governments Borrow?" Newsweek, October 29.

Shaoul, Raquel. 2005. “An Evaluation of Japan's Current Energy Policy in the Context of the Azedegan Oil Field Agreement Signed in 2004." Japanese Journal of Political Science 6, 3: 411-437.

Shealy, Malcolm, and James P. Dorian 2007. "Growing Chinese Energy Demand: Is the World in Denial?" A Report of the Energy and National Security Program, Center for Strategic and International Studies, October.

State Council. 2007. "China's Energy Conditions and Policies," Information Office of the State Council. Available at www.china.org.cn/english/whitepaper/ energy/237089.htm (accessed June 7, 2010).

Stringer, Kevin D. 2008. "Energy Security: Applying a Portfolio Approach." Baltic Security and Defence Review 10, 1: 121-142.

Takahashi, Manami. 2000. “Japan's Oil Sellers Set to Enter International Market." Platt's Oilgram, August 21.

Tow, William T. 2007. "Strategic Dimensions of Energy Competition in Asia." In Energy Security in Asia, ed. Michael Wesley, 161-173. New York: Routledge.

Vivoda, Vlado. 2008. The Return of the Obsolescing Bargain and the Decline of Big Oil: A Study of Bargaining in the Contemporary Oil Industry. Saarbrücken, Germany: VDM Verlag Dr. Müller.

- 2009. "Diversification of Oil Import Sources and Energy Security: A Key Strategy or an Elusive Objective?” Energy Policy 37, 11: 4615-4623.

_. 2010a. "Evaluating Energy Security in the Asia-Pacific Region: A Novel Methodological Approach.” Energy Policy 38, 9: 5258-5263.

_. 2010b. "International Oil Companies, US Government and Energy Security Policy: An Interest-based Analysis." International Journal of Global Energy Issues 33, 1-2: 73-88.

Wan, Zhihong. 2009. "Venezuela, China Ink \$16b Oil Deal.” China Daily, September 18 .

— 2010. "Wen Heads 'Super Ministry’ For Energy.” China Daily, January 28. 
Wu, Gang, Yi-Ming Wei, Ying Fan, and Lan-Cui Liu. 2007. “An Empirical Analysis of the Risk of Crude Oil Imports in China Using Improved Portfolio Approach." Energy Policy 35, 8: 4190-4199.

Xinhua Daily. 2006. "China Needs More Supertankers to Ensure Oil Supply Security: Report," August 14.

Xu, Xiaojie. 2002. China's Oil Strategy Toward the Middle East. Austin, TX: The James A. Baker III Institute for Public Policy of Rice University.

Xu, Yi-chong. 2006. "China's Energy Security." Australian Journal of International Affairs 60, 2: 265-286.

Yergin, Daniel. 1988. "Energy Security in the 1990s." Foreign Affairs 67, 1: 110-132.

Yokobori, Keiichi. 2005. "Japan.” In Energy and Security: Toward a New Foreign Policy Strategy, ed. Jan H. Kalicki and David L. Goldwyn, 305-328. Washington, DC: Woodrow Wilson Center Press.

Yorke, Valerie. 1983. "Oil, the Middle East and Japan's Search for Security.” In Japan's Economic Security, ed. Nobutoshi Akao, 45-70. New York: St. Martin's Press.

Zha, Daojiong. 2006. "China's Energy Security: Domestic and International Issues." Survival 48, 1: 179-190.

Ziegler, Charles E. 2010. "Neomercantilism and Energy Interdependence: Russian Strategies in East Asia." Asian Security 6, 1: 74-93. 